\title{
ДАЙДЖЕСТ
}

УДК 61:002.513 НЕОНІЛА ОЛЕГІВНА АРТАМОНОВА, ОЛЬГА МИКОЛАЇВНА МИРНА,
ЮЛІАНА ВАЛЕРІЇВНА ПАВЛІЧЕНКО

ДУ «Інститут медичної радіології та онкології ім. С. П. Григор’єва НАМН Украӥни», Харків

\section{СУЧАСНІ ЦИФРОВІ МЕДИЧНІ ТЕХНОЛОГІЇ}

\section{Інтернет речей (IP)}

Загальна інформація щодо Інтернету речей (IP)

Згідно з найбільш поширеним формулюванням, Інтернет речей (англ. Internet of Things) — це концепція обчислювальної мережі фізичних предметів («речей»), оснащених вбудованими технологіями для взаємодії одного з іншим або із зовнішнім середовищем, яка розглядає організацію таких мереж як явище, здатне перебудувати економічні та суспільні процеси, що виключає частину дій і операцій, для яких необхідна участь людини (рис. 1). У світових засобах масової інформації обговорюють майбутню технологічну революцію, яка торкнеться всіх і змінить наше життя так само, як колись виникнення і впровадження телебачення, персональних комп'ютерів або мережі Інтернет.

Поява технологій Інтернету речей (IP) спонукала до захоплюючих досягнень у XXI столітті. Тепер IP використовують не тільки у промисловості, але і в інших галузях. Так, сучасну охорону здоров'я вже важко уявити без IP. У результаті стрімкого розвитку технологій IP, у сфері охорони здоров'я відкриваються нові можливості. Зокрема, з огляду на те, як зросла популярність переносної електроніки і неінвазивних сенсорів, з'являються додатки електронної та мобільної охорони здоров'я, що реалізують персоналізований підхід.

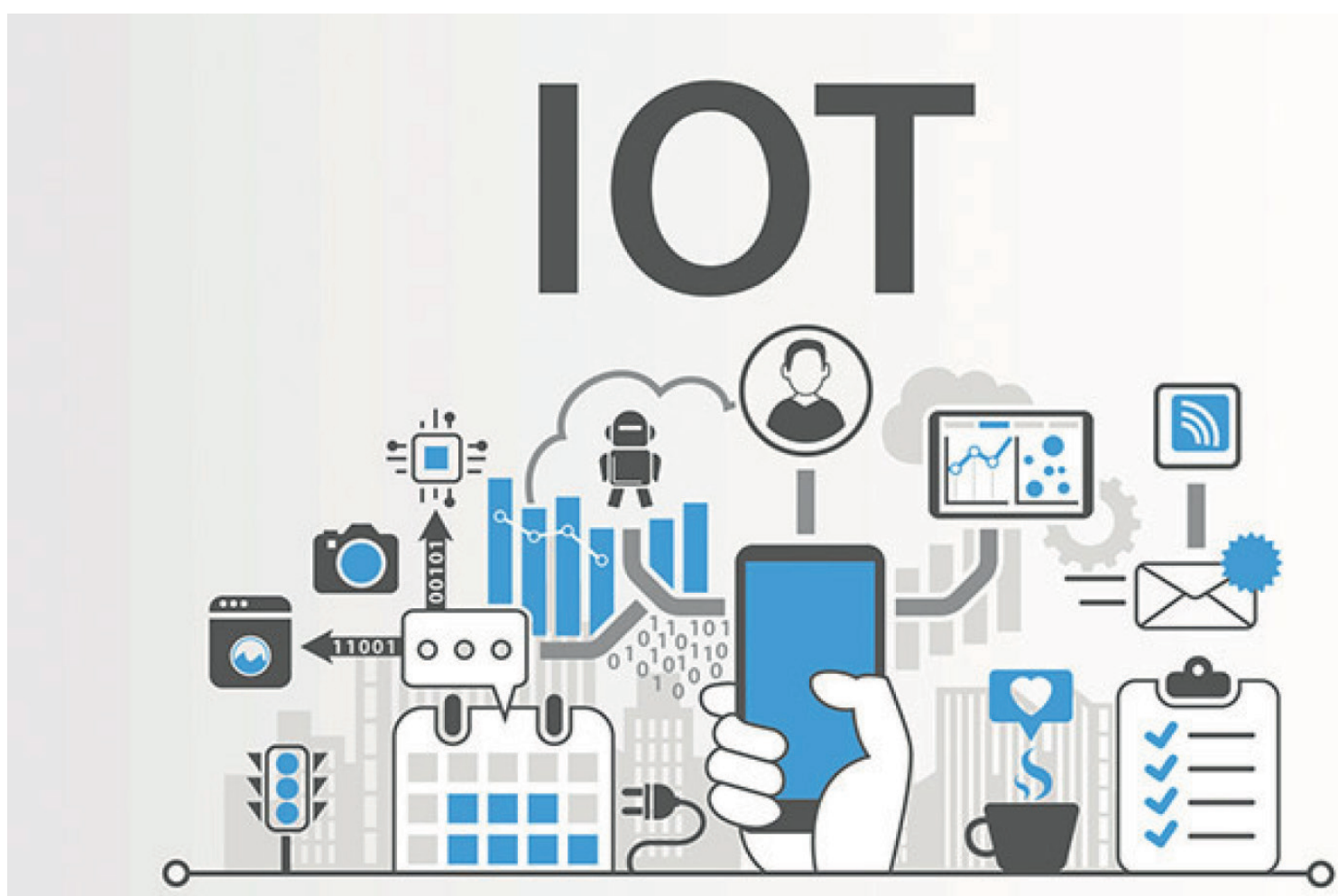

Рис. 1. Інтернет речей — мережа взаємозв'язків базового комп'ютера з різними речами (з відкритих джерел)

(C) Н. О. Артамонова, О. М. Мирна, Ю. В. Павліченко, 2020 
1. Розширення Інтернету речей (Iotx2) у майбутньому нерозривно пов'язане 3 медициною (Ai Driven advanced Internet Of Things (Iotx2): The future seems irreversibly connected in medicine) [1].

Мережа IP вже значно розширила можливості медицини i, безсумнівно, їх буде ще більше з використанням штучного інтелекту (Ш). Сьогодні мережі IP, керовані ШІ, можуть ефективно і результативно відстежувати найдрібніші деталі і кожну зустріч 3 медичним працівником для поліпшення моніторингу здоров'я пацієнтів, для раннього виявлення раку, для процесу його лікування, а також для спостереження і т. ін. На сьогодні $€$ значні досягнення у технологіях IP, проте ШІ, який керує ними, все ще перебуває на початковому етапі свого розвитку. Наприклад, розумні годинники, фітнес-трекери та інші смарт-пристрої, які можна носити, відстежують лише певні функції, наприклад, частоту серцевих скорочень, активність сну, тренування тощо. Якщо ви бажаєте відстежувати одразу кілька показників, наприклад, частоту дихання, артеріальний тиск тощо, слід носити кілька індивідуальних пристроїв, які виконують кожну функцію окремо. Сьогодні ще неможливо відстежити декілька показників за допомогою лише одного гаджета, це $є$ важливим фактором, який обмежує повний контроль медичного стану людини.

2. Цифровізація здоров'я у геріатричній онкології (Digital health for geriatric oncology) [2].

У цьому огляді описані сучасні цифрові рішення, пов'язані зі здоров'ям у галузі геріатричної онкології та можливістю застосування нових технологій дистанційного моніторингу здоров'я в контексті лікування онкологічних захворювань. Завдяки швидкому прогресу у технологіях Інтернет речей останніми роками було розроблено багато систем дистанційного оцінювання. Незважаючи на їх стрімкий розвиток у деяких сферах охорони здоров'я та надійну функціональність, ще досить мало таких рішень було розроблено або випробувано в онкологічних пацієнтів старшого віку. Результати повідомлення: для геріатричної онкології не вистачає консенсусного розуміння можливої кореляції між віддаленими цифровими оцінками та результатами, які пов'язані зі здоров'ям. Висновок: у майбутньому може бути здійснена розробка та проведення спільних досліджень за участю вчених-програмістів, онкологів та пацієнтів.

3. Мобільні додатки для реабілітації пацієнтів із задавненим раком легень, які отримують хіміотерапію: пілотне дослідження (Mobile phone App-Based pulmonary rehabilitation for chemotherapy-treated patients with advanced lung cancer: Pilot study) [3].

У пацієнтів із прогресуючим раком легенів в основному спостерігають хронічне захворювання легенів, зниження фізичної працездатності та інші симптоми, що призводять до зміни якості життя (ЗЯЖ). У дослідженні проведено оцінку легеневої реабілітації (ЛР) 3 використанням мобільних додатків та пристроїв «Інтернет речей» у хворих на прогресуючий рак легені, які проходять хіміотерапію. Всього в дослідженні було задіяно 100 пацієнтів 3 використанням PR-програми на базі програми для смартфону протягом 12 тижнів. Досліджували здатність навантаження (6 хвилин ходьби, 6MWD), ЗЯЖ, шкала симптомів та індекси дистресу. У цілому 90 пацієнтів пройшли програму PR. Висновки: PR на основі додатків для смартфонів являє собою ефективну і здійсненну програму для поліпшення фізичної працездатності, управління симптомами і дистресом у пацієнтів із задавненим раком легені, які проходять хіміотерапію.

4. Радіологія, мобільні пристрої та Інтернет речей (Radiology, mobile devices, and Internet of Things (IoT)) [4].

Радіологія за своєю природою нерозривно пов'язана з Інтернетом, тому є лідером серед інших сфер медицини завдяки кількості технологій. Багато додатків у практичній радіології базуються на Інтернеті речей.

Упровадження мобільних пристроїв та їх інтеграція в робочий процес обробки зображень підвищує роль IP в радіології. У статті коротко обговорюється значення IP у роботі із зображеннями, а також у поточних і потенційних додатках, показано, як мобільні пристрої можуть бути інтегровані в робочі процеси радіології, а також вплив IP на освіту, дослідження та обслуговування радіологічних пацієнтів.

5. Дослідження та отримання даних про використання медичних обладнань у мережі Інтернет речей (Exploration and minging of large medical equipment operation data under Internet of Things) [5].

3 розвитком технологій у галузі Інтернету речей стало невід'ємним використання IP та хмарних обчислювальних технологій для підвищення ефективності управління медичним обладнанням. У цій статті описано використання КТ як вибірки для збору та аналізу даних за допомогою технології IP. Отриманий позитивний результат свідчить про безперечну користь дослідження.

6. Інновації у хірургії/операційному відділі, медичні пристрої, керовані Інтернетом речей (Innovation in surgery/operating room driven by Internet of Things on medical devices) [6].

Мета дослідження - перевірити, чи можливо «візуалізувати використання інструменту в конкретних процедурах» шляхом автоматичного накопичення цифрових даних, пов'язаних із поведінкою хірургічних інструментів (щипців у лапароскопічній хірургіï). П'ятеро сертифікованих хірургів (закінчили аспірантуру 9-24 роки тому) провели лапароскопічну холецистектомію на 5-ти свинях. Радіочастотний ідентифікатор (RFID) був прикріплений до кожних щипців за допомогою зчитувачів RFID, встановлених зліва/справа від операційного стола. Автоматично було записано поведінку хірургів з відстеженням щипців у правій/лівій руці оператора за допомогою RFID. Результати з використанням IP для хірургічних процедур можуть бути «візуалізовані», що має підвищити безпеку операцій за рахунок оптимального використання хірургічних пристроїв, 
правильного застосування електрокоагуляції і стандартизації хірургічних процедур.

Загальна інформація щодо інтернет-технології блокчейн

Блокчейн (англ. Blockchain — побудований за певними правилами безперервний послідовний ланцюг блоків (пов’язаний список), що містить інформацію про них (рис. 2). Сутність блокчейну як систематизованої бази даних, що зберігається не на одному сервері, а реплікується на тисячах комп'ютерів, відповідає завданням сучасної медицини. Додатковою перевагою є акумуляція інформації в інформаційних блоках, що дозволяє створити ланцюжки взаємозалежних блоків, які дублюються на всіх комп'ютерах системи. При цьому інформація тільки примножується, але не втрачається і не спотворюється.

В охороні здоров'я блокчейн знаходить своє застосування в таких напрямках: зберігання даних електронних медичних карт; відстеження лікарських препаратів; контроль розподілу бюджетних коштів; збір даних для клінічних досліджень; забезпечення достовірності даних клінічних досліджень; збір коштів (краудфандинг) на інноваційні розробки.

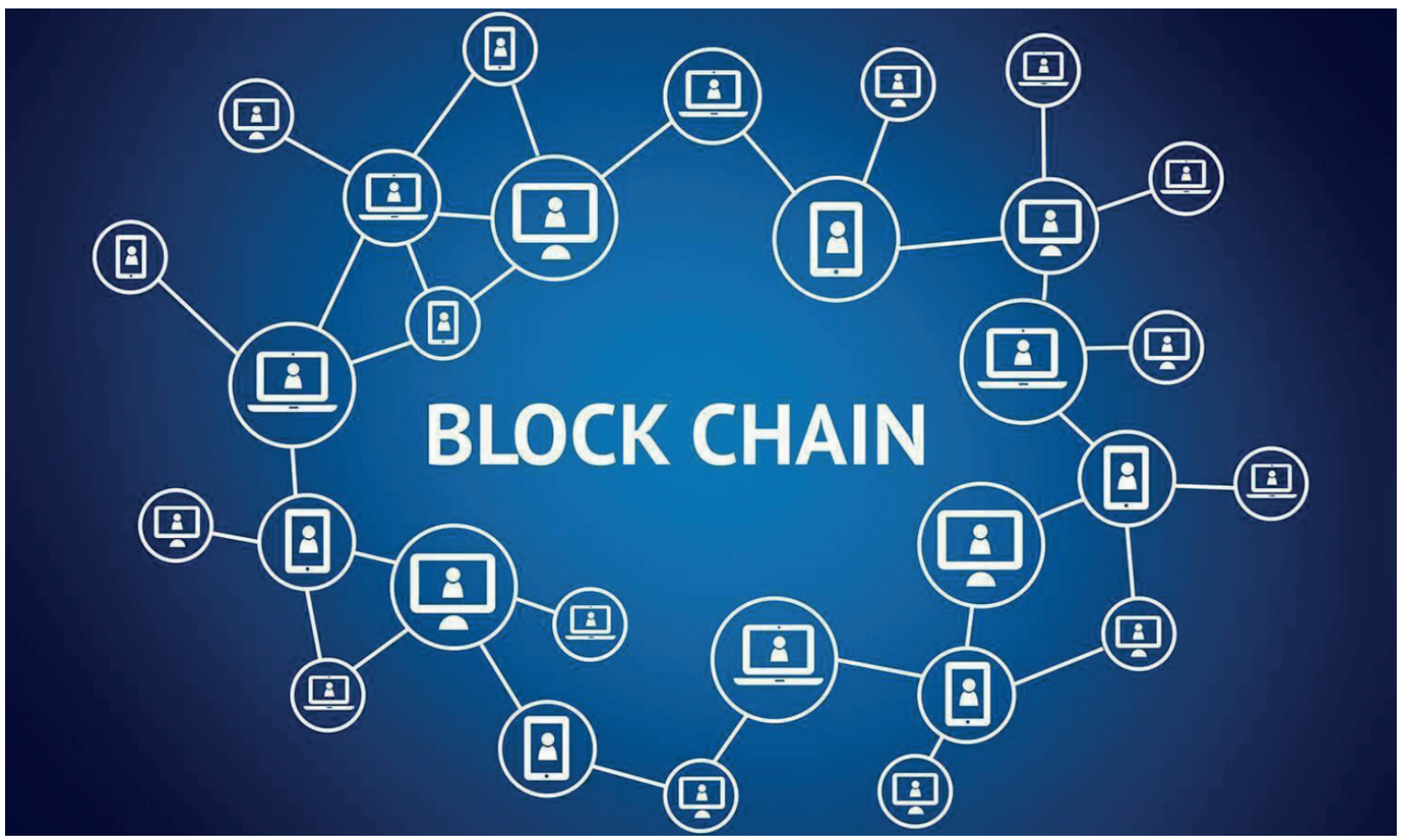

Рис. 2. Блокчейн - ланцюжок блоків транзакцій (за даними https://profitgid.ru/)

7. Застосування технології «блокчейн» для обміну даними в онкологіï: результати систематики (Applications of blockchain technology for data-sharing in oncology: Results from a systematic) [7].

В огляді наведено аналіз мотивацій, переваг, обмежень, а також бар'єрів, з якими стикаються при застосуванні додатків, основою яких є блокчейн, у сфері онкології. Своєчасний обмін електронними медичними записами про результати лікування і спостереження за хворими на рак має забезпечити належний моніторинг і своєчасне надання медичної допомоги пацієнтам. Використання технології «блокчейн» було підтримано дослідними співтовариствами, оскільки вважається перспективним напрямком досліджень. Утім, більшість рішень перебувають на рівні прототипу, а системи управління медичними даними на основі блокчейн поки що не створені. У даній роботі представлено систематичний огляд літератури для аналізу мотивацій, переваг та обмежень, а також бар'єрів і майбутніх проблем, які зустрічаються при застосуванні сучасних технологій «блокчейн» в онкології.
8. Роль блокчейн-технологій в управлінні медичною інформацією: оглядове дослідження (Attitudes toward blockchain technology in managing medical information: Survey study) [8].

Метою цього дослідження була оцінка ставлення лікарів та пацієнтів до використання блокчейн-технології, а також інтерпретування результатів у рамках теорії очікування. Проведено анкетування серед лікарів $(n=90)$ та пацієнтів $(n=90)$, у якому оцінено їх ставлення до використання блокчейн-технології в управлінні та розповсюдженні медичної інформації. Відповіді оцінювалися за шкалою, яка варіювалася від 1 (дуже негативно) до 7 (дуже позитивно). У результаті лікарі (в середньому 3,7-5,0) виявили більш негативне ставлення до блокчейн-технології, ніж пацієнти (в середньому 6,3-6,8).

9. Обмін інформацією у хмарних технологіях у сфері охорони здоров'я на основі консенсус-орієнтованої блокчейн-технології: тематичне дослідження служби діагностики пухлин молочної залози (Cloud health resource 
sharing based on consensus-oriented blockchain technology: Case study on a breast tumor diagnosis service) [9].

У цьому дослідженні запропонована модель хмарного обміну інформацією для охорони здоров'я, яка грунтується на консенсус-орієнтованій блокчейнтехнології, а також проведено імітаційне дослідження діагностики пухлин молочної залози. Запропонована платформа побудована на об'єднаній блокчейн-технології, яка виконує функції централізації та децентралізації. Консенсусні механізми формуються за встановленими стандартами для запропонованої моделі. Відкритий код Ethereum використовується для функціонування блокчейн-технології. Перевагою є можливість вибору сформованого погодженого алгоритму блоку. Запропонована модель створена на основі імітаційного тематичного дослідження служби діагностики пухлин молочної залози, а також може використовуватись для інших додатків.

10. Вивчення потенціалу технології «блокчейн» для забезпечення японської охорони здоров'я XXI століття: точка зору та політика (Examining the potential of blockchain technology to meet the needs of 21st-century Japanese health care: Viewpoint on use cases and policy) [10].

В Японії відбувається старіння нації у зв'язку iз низьким рівнем народжуваності. Отже, перед Японією постає нове завдання щодо змін у системі охорони здоров'я, створення моделі універсального охоплення здоров'я (УОЗ), яка охоплює послуги охорони здоров'я в усьому світі. Конкретні проблеми, що можливі у системі охорони здоров'я Японії: збільшення національних витрат у цьому напрямку, зростання попиту на медичні послуги, гостра потреба у догляді за хворими, дефіцит медичних працівників та нерівність доступу до охорони здоров'я між сільською та міською місцевістю. Технологія «блокчейн» має здатність вирішення деяких із цих проблем, але тільки якщо вона концептуалізована, спроектована, локалізована і розгорнута таким способом, який сумісний із централізованою системою охорони здоров'я, орієнтованою на УОЗ. Блокчейн-рішення мають бути адаптивними до можливих унікальних бар'єрів, до національної політики в галузі охорони здоров'я та інновацій Японії та до іiі регулюючої системи «пісочниці», а також прагнути витягти урок 3 прийняття блокчейн-технології у приватному секторі інших країн. Ця точка зору ілюструє основні можливості та ускладнення, які можуть виникнути під час упровадження блокчейн-технології для майбутньої охорони здоров'я Японії.

11. Розробка безпечної схеми обміну медичними даними на основі блокчейну (Design of a secure medical data sharing scheme based on blockchain) [11].

Функція децентралізації блокчейну корисна для вирішення багатьох проблем, де процес захищеної аутентифікації значною мірою залежить від третьої довіреної сторони, яка забезпечує безпеку передачі даних. У цій роботі технологія блокчейну використовується для опису вимог безпеки у процесі аутентифікації і запропонована мережева модель медичної кібер-фізичної системи
(МКФС), в основу якої входить блокчейн. Аналізуючи архітектуру зберігання медичних даних, можна переконатися, що дані не можуть бути підроблені та відслідковані. На етапі аутентифікації безпеки біліарне відображення та нерозв'язні проблеми можуть використовуватися для усунення загрози безпеці у процесі аутентифікації постачальників медичних даних та користувачів. Для аналізу протоколів безпеки використовується логіка натільної комп'ютерної мережі (BAN), а також проводиться формальний аналіз і порівняння протоколів безпеки. Результати демонструють, що МКФС на базі блокчейну не тільки містить загальні дані про медичне обслуговування, а також відповідає різним вимогам безпеки на етапі перевірки аутентифікації безпеки. Крім того, витрати на зберігання та розрахункові роботи мінімальні, тому запропонована схема підходить для безпечного обміну великими медичними даними.

12. Блокчейн-технології: принципи та застосування в медичній візуалізації (Blockchain technology: Principles and applications in medical imaging) [12].

У статті обговорюються концепції і принципи, що лежать в основі технології блокчейну, і додатки, що належать до медичної візуалізації, потенційні проблеми доступу до відкритого і приватного ключів, обмеження за розміром, швидкістю, складністю та безпекою. Можливі варіанти використання блокчейну, які належать до медичної візуалізації, включають у себе обмін зображеннями, право власності у пацієнтів на зображення, відстеження імплантованих медичних пристроїв, дослідження, телерадіологію і штучний інтелект. Незважаючи на те, що блокчейн пропонує захоплюючі способи полегшення зберігання та розповсюдження медичних зображень, він має кілька ключових обмежень, про які повинні знати медичні працівники, що працюють 3 медичними зображеннями, та фахівці з інформатики.

\section{Штучний інтелект (ШІ)}

Загальна інформація щодо інтернет-технології штучного інтелекту (ШІ)

Штучний інтелект (англ. artificial intelligence, AI) здатність інтелектуальних систем виконувати творчі функції, які традиційно виконує людина; наука та технологія створення інтелектуальних машин, особливо інтелектуальних комп'ютерних програм (рис. 3). Штучний інтелект у медицині використовує алгоритми і програмне забезпечення для апроксимації людських знань при аналізі складних медичних даних. Основною метою додатків, пов'язаних зі здоров'ям людини, є аналіз взаємозв'язку між методами профілактики або лікування і результатами лікування пацієнтів. Були розроблені і застосовані на практиці програми Ш, які проводять діагностику процесів, розробку протоколів лікування, розробку лікарських засобів, моніторинг стану пацієнта.

Ефективне застосування інформаційних технологій для прогнозування захворювань у різних сферах медичних знань - онкологіі, офтальмології та кардіології може значно підвищити відсоток виживаності пацієнтів. Упровадження в клінічну практику інформаційних технологій, зокрема штучного інтелекту на основі 
нейронних мереж, може автоматизувати аналіз лікувально-діагностичної інформації і видачу результатів швидше і точніше, ніж усі існуючі технології. Штучний інтелект пропонує можливості безперервного моніторингу і більш точної диференціальної діагностики захворювань у поєднанні з мінімальними тимчасовими витратами. Найсучасніші методи діагностики, безперечно, включають використання штучного інтелекту.
Сучасні системи і сервіси Ш так само мають прогресивні напрямки розвитку. По-перше, системи діалогу, де система запитує у пацієнта інформацію і робить висновок. По-друге, системи аналізу зображень, які аналізують зображення і встановлюють діагноз захворювання. Останній напрям заслуговує на особливу увагу і детальне вивчення, позаяк система може «побачити» захворювання там, де його не знайде людина.

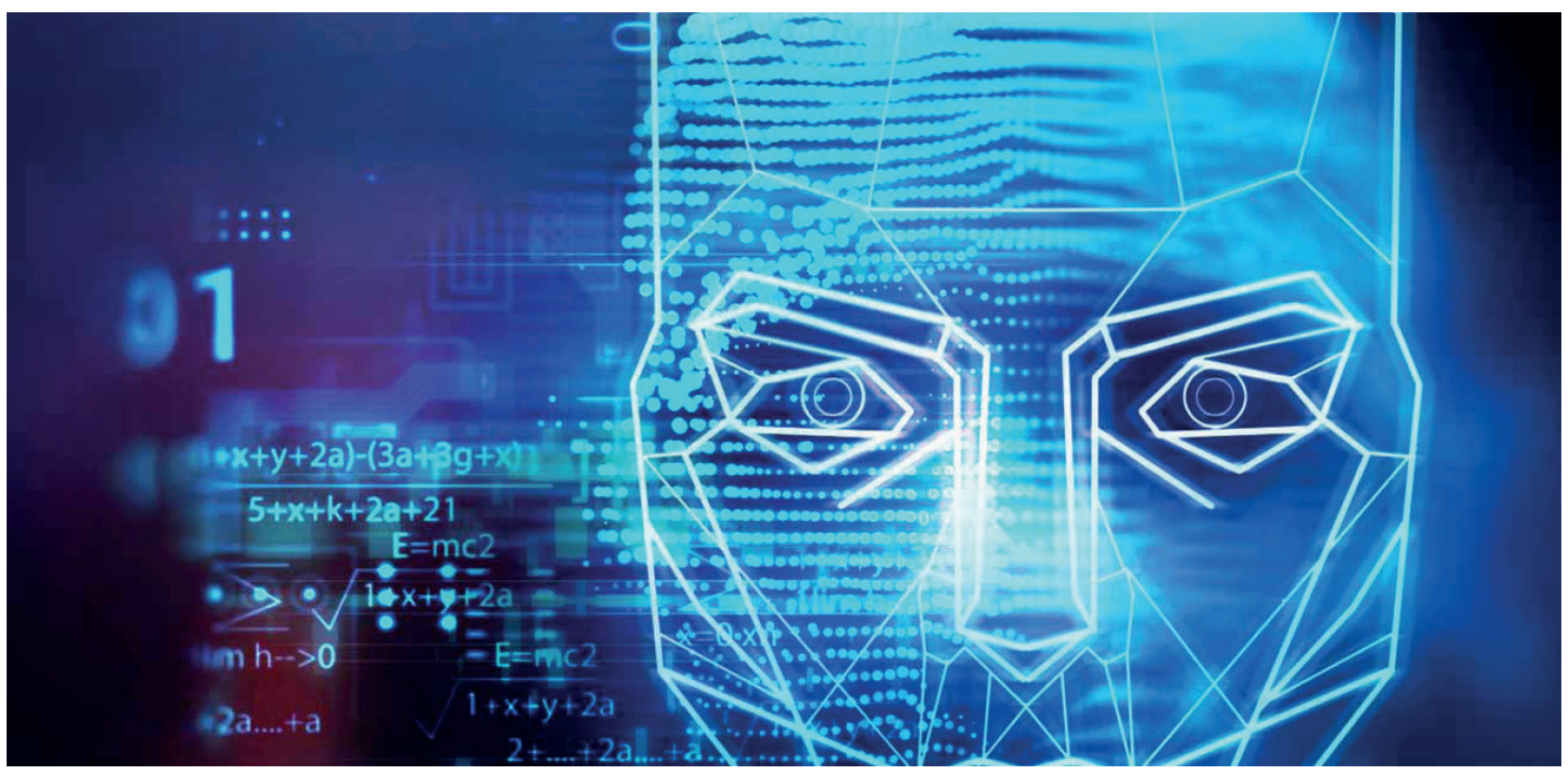

Рис. 3. Штучний інтелект - робот (з відкритих джерел)

13. Ставлення китайських онкологічних хворих до використання штучного інтелекту (Attitudes of Chinese cancer patients toward the clinical use of artificial intelligence) [13].

Штучний інтелект відіграє важливу роль у багатьох сферах медицини. Утім все ще немає доказів, які підтверджують, що онкологічні хворі не будуть заперечувати клінічне використання Ш. Проведено анкетування 527 онкологічних пацієнтів, які проінформовані про свій діагноз. Повернення анкет складає 76,3 \%. Більшість онкологічно хворих позитивно реагують на використання Ш на обох стадіях: діагностики та лікування, учасники, які проінформовані про Ш, були більш схильні застосовувати його на етапі діагностики. Проте в основному опитувані вважають, що дослідження лікарів-онкологів $€$ більш надійними. Більшість учасників припускають, що Ш допоможе лікарям-онкологам у майбутньому, та мало хто впевнений, що Ш має замінити їх повною мірою.

14. Штучний інтелект для діагностики, оцінки та біопсії раку передміхурової залози: популяційне діагностичне дослідження (Artificial intelligence for diagnosis and grading of prostate cancer in biopsies: a population-based, diagnostic study) [14].

У роботі запропоновано систему діагностики раку передміхурової залози, основою якої $є$ штучний інтелект. Під час популяційного шведського дослідження - STHLM3, проведеного у період 2012-2014 pp., оцифровано 6682 біоптатів від 976 випадково відібраних учасників віком 50-69 років. Отримані зображення використовували для вивчення впливу глибоких нейронних мереж на оцінку біопсії простати. Мережі були оцінені шляхом прогнозування наявності злоякісних тканин та оцінки їх ступеня за шкалою Глісона. Оцінена також ефективність результатів на 87 біопсіях, кожна 3 яких була оцінена 23 досвідченими урологічними патологами з International Society of Urological Pathology. У результаті зроблено висновок, що система ШІ може бути застосована для виявлення і оцінки раку у зразках біопсії простати на рівні, який можна порівняти з рейтингом міжнародних експертів патології простати. Клінічне застосування цієї технології повинно знизити навантаження на патологів, а система Ш може допомогти у стандартизації оцінки.

15. Використання штучного інтелекту у клінічній практиці [15].

У статті проаналізовано досвід застосування Ш у клінічній практиці. Дослідження показало, що нейронні мережі вже 3 успіхом функціонують у найрізноманітніших галузях клінічної практики, в першу чергу при аналізі цифрових діагностичних зображень у рентгенології та роботі датчиків життєво важливих функцій; виявленні закономірностей у різнорідній клінічній інформації електронних медичних карток. Діагностична точність систем на основі Ш за деякими патологіями наближається до рівня точності діагностики провідних медичних експертів. Найбільш перспективним напрямком застосування Ш в медицині 
$€$ впровадження автоматизованих систем діагностики в існуючі інформаційні системи медичних організацій. Показано, що застосування ШІ в охороні здоров'я має такі основні особливості: Ш ефективний щодо обмеженого кола патологій, при оцінці великих масивів даних (big data), зокрема архівів PACS, для пошуку прихованої і пропущеної при діагностиці патології, але не може застосовуватися для самостійного виставлення діагнозу, однак ефективний у системах підтримки прийняття рішень, де останнє слово залишається за лікарем.

16. Реалізація ефективних моделей класифікації медичних даних методами інтелектуального аналізу текстової інформації [16].

Стаття присвячена розробці та реалізації ефективних моделей класифікації медичних даних методами інтелектуального аналізу текстової інформації для підтримки прийняття рішень при діагностиці пульмонологічних захворювань у дітей і підлітків. У структурованому вигляді, як правило, зберігаються результати аналізів, зокрема анамнези, результати оглядів, описи результатів обстежень, які мають неструктуровану форму (у вигляді текстів на природній мові). У роботі дана оцінка якості розроблених методів і моделей добування інформації
3 клінічних текстів російською мовою. Проведено оцінку методу автоматичної діагностики пульмонологічних захворювань на тестовій вибірці. Визначено найбільш інформативні ознаки, а також відповідні методи машинного навчання для класифікації пацієнтів за групами захворювань. Застосування методів інтелектуального аналізу і обробки даних дасть можливість автоматизувати рішення багатьох медичних завдань, що виникають у клінічній практиці, підвищивши тим самим якість первинної медичної допомоги.

17. Аналіз результатів комп'ютерної томографії головного мозку за допомогою згортувальної нейронної мережі [17].

Штучний інтелект широко використовується в різних дослідженнях. Нейронні мережі є одним із найбільш поширених і оптимальних алгоритмів для роботи iз зображеннями. Результати розпізнавання зображень використовуються для аналізу результатів медичних обстежень пацієнтів. Предметом дослідження є аналіз результатів комп'ютерної томографії головного мозку людини за допомогою згортувальної нейронної мережі, створеної на основі бібліотеки Keras.

\section{СПИСОК ВИКОРИСТАНОЇ ЛІТЕРАТУРИ}

1. Ergen O. Ai Driven advanced Internet of Things (Iotx2): The future seems irreversibly connected in medicine / O. Ergen, K. D. Belcastro // Anatol. J. Cardiol. — 2019. — Vol. 22, Suppl 2. — P. 15-17. doi: 10.14744/AnatolJCardiol.2019.73466.

2. Digital health for geriatric oncology / R. Fallahzadeh, S. A. Rokni, H. Ghasemzadeh et al. // JCO Clin. Cancer Inform. 2018. — № 2. — P. 1-12. doi: 10.1200/CCI.17.00133.

3. Mobile phone App-Based pulmonary rehabilitation for chemotherapy-treated patients with advanced lung cancer: Pilot study / S. Park, J. Y. Kim, J. C. Lee et al. // JMIR Mhealth Uhealth. — 2019. — Vol. 7, № 2. — P. e11094. doi: 10.2196/11094.

4. Radiology, mobile devices, and Internet of Things (IoT) [Электронный pecypc] / S. Gupta, E. M. Johnson, J. G. Peacock et al. // J. Digit. Imaging. — 2020. — Режим доступа : https://link.springer.com/article/10.1007\%2Fs10278-019-00311-2. — Загл. 3 екрану. — doi: 10.1007/s10278-019-00311-2.

5. Zhang J. Exploration and minging of large medical equipment operation data under Internet of Things / J. Zhang, Z. Jin, Y. Shen // Zhongguo Yi Liao Qi Xie Za Zhi. — 2019. — Vol. 43, № 5. — P. 330-333. doi: 10.3969/j.issn.1671-7104.2019.05.005.

6. Innovation in surgery/operating room driven by Internet of Things on medical devices / Y. Ushimaru, T. Takahashi, Y. Souma et al. // Surg. Endosc. — 2019. — Vol. 33, № 10. — P. 3269-3477. doi: 10.1007/s00464-018-06651-4.

7. Applications of blockchain technology for data-sharing in oncology: Results from a systematic literature review / A. Dubovitskaya, P. Novotny, Z. Xu et al. // Oncology. — 2019. — P. 1-9. doi: 10.1159/000504325.

8. Attitudes toward blockchain technology in managing medical information: Survey study / Y. S. Hau, J. M. Lee, J. Park et al. // J. Med. Internet. Res. — 2019. — Vol. 12, № 21. — P. e15870. doi: 10.2196/15870.

9. Zhu X. Cloud health resource sharing based on consensus-oriented blockchain technology: Case study on a breast tumor diagnosis service / X. Zhu, J. Shi, C. Lu // J. Med. Internet. Res. — 2019. — Vol. 21, № 7. — P. e13767. doi: 10.2196/13767.

10. Examining the potential of blockchain technology to meet the needs of 21 st-century Japanese health care: Viewpoint on use cases and policy / T. Mackey, H. Bekki, T. Matsuzaki et al. // J. Med. Internet Res. — 2020. — Vol. 22, № 1. — P. e13649. doi: 10.2196/13649.

11. Design of a secure medical data sharing scheme based on blockchain / X. Cheng, F. Chen, D. Xie et al. // J. Med. Syst. — 2020. — Vol. 44, № 2. — P. 52. doi: 10.1007/s10916-019-1468-1.

12. McBee M. P. Blockchain Technology: Principles and applications in medical imaging [Электронный pecypc] / M. P. McBee, C. Wilcox // J. Digit. Imaging. — 2020. — Режим доступа : https://link.springer.com/article/10.1007\%2Fs10278-019-00310-3. — Загл. з екрану. doi: 10.1007/s10278-019-00310-3

13. Attitudes of Chinese cancer patients toward the clinical use of artificial intelligence / K. Yang, Z. Zeng, H. Peng et al. // Patient Prefer Adherence. — 2019. — Vol. 13, № 1. — P. 1867-1875. doi: 10.2147/PPA.S225952.

14. Artificial intelligence for diagnosis and grading of prostate cancer in biopsies: a population-based, diagnostic study / P. Ström, K. Kartasalo, H. Olsson et al. // Lancet Oncol. — 2020. — Vol. 21, № 2. — P. 222-232. doi: 10.1016/S1470-2045(19)30738-7.

15. Использование искусственного интеллекта в клинической практике / Д. Н. Борисов, И. И. Кушнирчук, В. В. Севрюков, Е. И. Коваленко // Клиническая патофизиология. - 2019. — № 2. - С. 26-31. 
16. Реализация эффективных моделей классификации медицинских данных методами интеллектуального анализа текстовой информации / О. С. Кротова, И. В. Москалев, Л. А. Хворова, О. М. Назаркина // Изв. Алтайского гос. университета. 2020. — № 1 (111). — C. 99-104. URL: http://izvestiya.asu.ru/article/view/\%282020\%291-16.

17. Ван Цзи. Анализ результатов компьютерной томографии головного мозга с помощью сверточной нейронной сети / Цзи Ван, В. И. Воронов // DSPA: Вопросы применения цифровой обработки сигналов. — 2020. — № 1. — C. 32-40. http://mediapublisher.ru/wp-content/uploads/DSPA-1-2020.pdf\#page=32

Стаття надійшла до редакції 16.03.2020.

\section{Контактна інформація:}

Артамонова Неоніла Олегівна

д-р наук із соціал. комунікацій, канд. біол. наук, ст. наук. співроб., керівник групи наукового аналізу і моніторингу інтелект. власності ДУ «ІМРО НАМН України»

вул. Пушкінська, 82, м. Харків, 61024, Україна

тел.: +38 (057) 725-50-30

E-mail:imr@ukr.net 